LOcKHEED matin

ENVIRONMENTAL RESTORATION PROGRAM

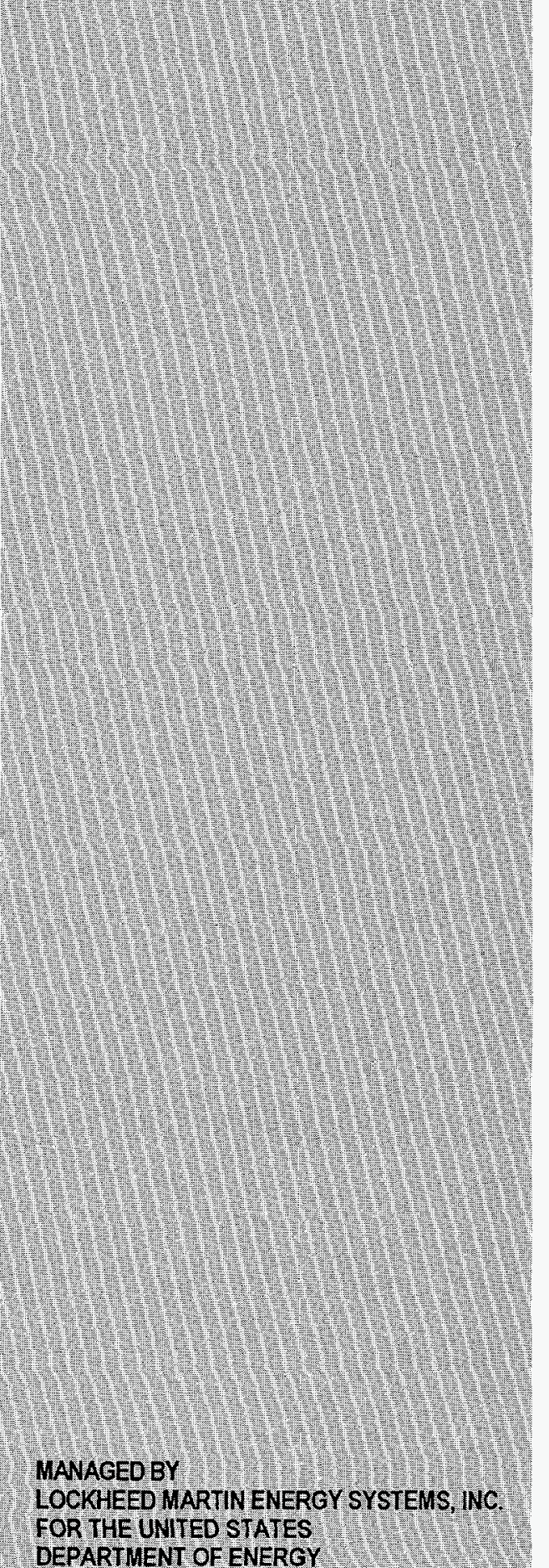

DEPARTMENT OF ENERGY
Y/ER-276

\section{Surveillance and Maintenance Report on Decontamination and Decommissioning and Remedial Action Activities at the Oak Ridge Y-12 Plant, Oak Ridge, Tennessee}

Fiscal Year 1996
This document has been approved by the Y-12 Plant Technical Information Office for release to the public. Date: $11 / 26 / 96$

ENERGY SYSTEMS

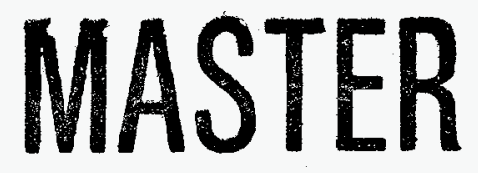

DISTRIBUTION OF THIS DOCUMENT IS UNLATED

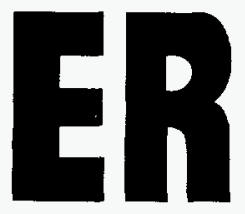

$>2$ 

Energy Systems Environmental Restoration Program

Surveillance and Maintenance Report on Decontamination and Decommissioning and Remedial Action Activities at the Oak Ridge Y-12 Plant

Oak Ridge, Tennessee

Fiscal Year 1996

\author{
H. L. King \\ M. L. Sollenberger \\ D. E. Sparkman \\ R. M. Reynolds \\ G. S. Wayland
}

Date Issued-December 1996

\author{
Prepared for the \\ U.S. Department of Energy \\ Office of Environmental Management \\ under budget and reporting code EW 20 \\ Environmental Management Activities at the \\ OAK RIDGE Y-12 PLANT \\ Oak Ridge, Tennessee 37831-8169 \\ managed by \\ LOCKHEED MARTIN ENERGY SYSTEMS, INC. \\ for the \\ U.S. DEPARTMENT OF ENERGY \\ under contract DE-AC05-84OR21400
}




\section{DISCLAMMER}

Portions of this document may be illegible in electronic image products. Images are produced from the best available original document. 


\section{DISCLAIMER}

This report was prepared as an account of work sponsored by an agency of the United States Government. Neither the United States Government nor any agency thereof, nor any of their employees, make any warranty, express or implied, or assumes any legal liability or responsibility for the accuracy, completeness, or usefulness of any information, apparatus, product, or process disclosed, or represents that its use would not infringe privately owned rights. Reference herein to any specific commercial product, process, or service by trade name, trademark, manufacturer, or otherwise does not necessarily constitute or imply its endorsement, recommendation, or favoring by the United States Government or any agency thereof. The views and opinions of authors expressed herein do not necessarily state or reflect those of the United States Government or any agency thereof. 


\section{DISCLAIMER}

This report was prepared as an account of work sponsored by an agency of the United States Government. Neither the United States Government nor any agency thereof, nor any of their employees, makes any warranty, express or implied, or assumes any legal liability or responsibility for the accuracy, completeness, or usefulness of any information, apparatus, product, or process disclosed, or represents that its use would not infringe privately owned rights. Reference herein to any specific commercial product, process, or service by trade name, trademark, manufacturer, or otherwise does not necessarily constitute or imply its endorsement, recommendation, or favoring by the United States Government or any agency thereof. The views and opinions of authors expressed herein do not necessarily state or reflect those of the United States Government or any agency thereof. 


\section{PREFACE}

This Surveillance and Maintenance Report on Decontamination and Decommissioning and Remedial Action Activities at the Oak Ridge Y-12 Plant, Oak Ridge Tennessee: Fiscal Year 1996 (Y/ER-276) was prepared to communicate the accomplishments of the programs during fiscal year 1996. The decontamination and decommissioning work was performed under the Work Breakdown Structure element 1.4.12.1.2.01.10 (Activity Data Sheet 2701, "D\&D Surveillance and Maintenance"). The remedial actions were performed under the Work Breakdown Structure element 1.4.12.1.06.10 (Activity Data Sheet 2306, "S\&M Remedial Actions"). Publication of this document meets the milestone date of December 31, 1996. 


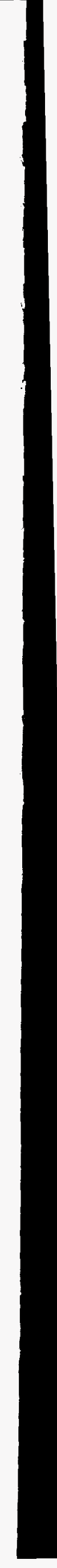




\section{CONTENTS}

PREFACE $\ldots \ldots \ldots \ldots \ldots \ldots \ldots \ldots \ldots \ldots \ldots \ldots \ldots \ldots \ldots \ldots \ldots \ldots \ldots \ldots \ldots \ldots \ldots \ldots \ldots \ldots$

FIGURES $\ldots \ldots \ldots \ldots \ldots \ldots \ldots \ldots \ldots \ldots \ldots \ldots \ldots \ldots \ldots \ldots \ldots \ldots \ldots \ldots \ldots \ldots \ldots \ldots$ vii

ABBREVIATIONS $\ldots \ldots \ldots \ldots \ldots \ldots \ldots \ldots \ldots \ldots \ldots \ldots \ldots \ldots \ldots \ldots \ldots \ldots \ldots \ldots \ldots \ldots$

EXECUTIVE SUMMARY $\ldots \ldots \ldots \ldots \ldots \ldots \ldots \ldots \ldots \ldots \ldots \ldots \ldots \ldots \ldots \ldots \ldots$

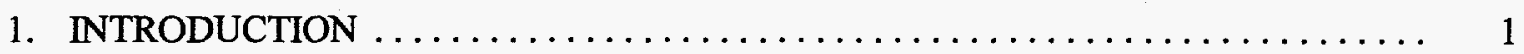

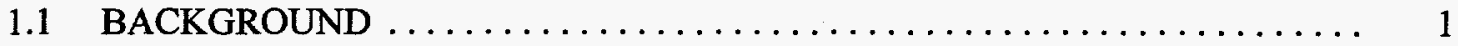

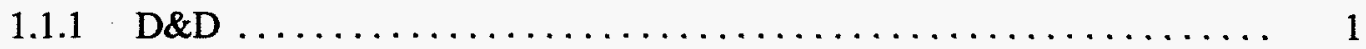

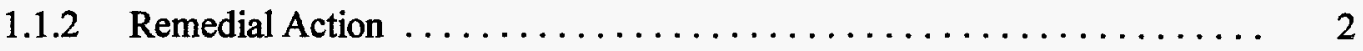

1.2 OBJECTIVES OF THE Y-12 PLANT ER DECONTAMINATION AND DECOMMISSIONING/REMEDIAL ACTION PROGRAMS .......... 2

1.2.1 Technical Objectives ............................ 2

1.2.2 Management Objectives $\ldots \ldots \ldots \ldots \ldots \ldots \ldots \ldots \ldots \ldots \ldots \ldots \ldots \ldots \ldots \ldots$

2. FISCAL YEAR 1996 SURVEILLANCE $\ldots \ldots \ldots \ldots \ldots \ldots \ldots \ldots \ldots \ldots \ldots \ldots \ldots$

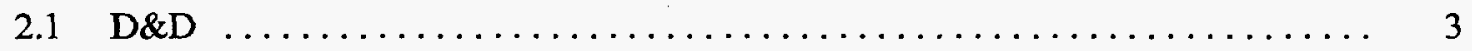

2.2 REMEDIAL ACTION SURVEILLANCE AND INSPECTION . . . . . . . 4

3. SAFETY AND SECURITY/PROTECTION SYSTEMS $\ldots \ldots \ldots \ldots \ldots \ldots \ldots \ldots \ldots$

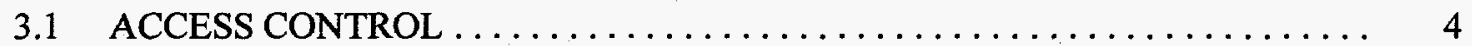

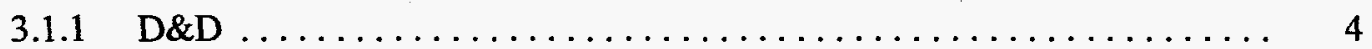

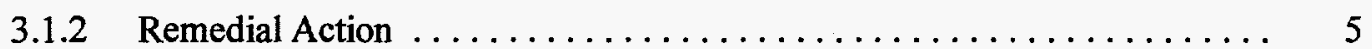

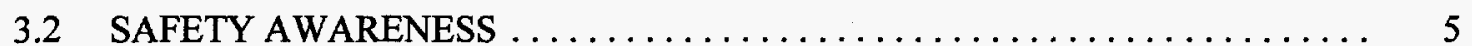

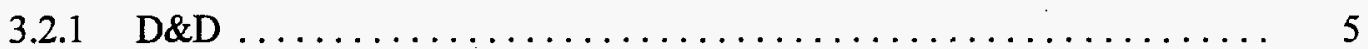

3.2.2 Remedial Action $\ldots \ldots \ldots \ldots \ldots \ldots \ldots \ldots \ldots \ldots \ldots \ldots \ldots \ldots$

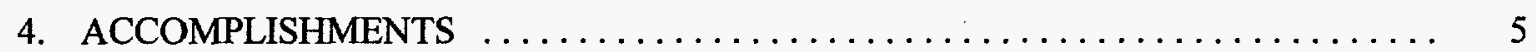

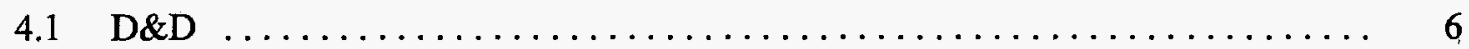

4.2 REMEDIAL ACTION $\ldots \ldots \ldots \ldots \ldots \ldots \ldots \ldots \ldots \ldots \ldots \ldots \ldots \ldots \ldots \ldots \ldots \ldots \ldots \ldots$

5. GOALS FOR FISCAL YEAR $1997 \ldots \ldots \ldots \ldots \ldots \ldots \ldots \ldots \ldots \ldots \ldots \ldots \ldots$

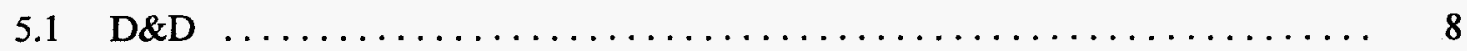

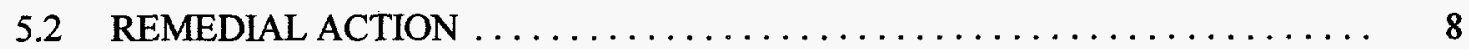

Appendix. REPRESENTATIVE FIGURES AND SITE MAP $\ldots \ldots \ldots \ldots \ldots \ldots \ldots \ldots$ A-1 



\section{FIGURES}

A.1 Zone 17 mercury vapor levels for six-month period, $1993-1996 \ldots \ldots \ldots \ldots \ldots$ A-3

A.2 Zone 18 mercury vapor levels for six-month period, $1993-1996 \ldots \ldots \ldots \ldots \ldots$ A-5

A.3 Completed decontamination area $\ldots \ldots \ldots \ldots \ldots \ldots \ldots \ldots \ldots \ldots \ldots \ldots \ldots \ldots$

A.4 Safety upgrades $\ldots \ldots \ldots \ldots \ldots \ldots \ldots \ldots \ldots \ldots \ldots \ldots \ldots \ldots \ldots \ldots \ldots \ldots \ldots$

A.5 Permitted RCRA storage area $\ldots \ldots \ldots \ldots \ldots \ldots \ldots \ldots \ldots \ldots \ldots \ldots \ldots \ldots \ldots \ldots \ldots \ldots \ldots$

A.6 Mercury and lithium hydroxide treatment area $\ldots \ldots \ldots \ldots \ldots \ldots \ldots \ldots \ldots$

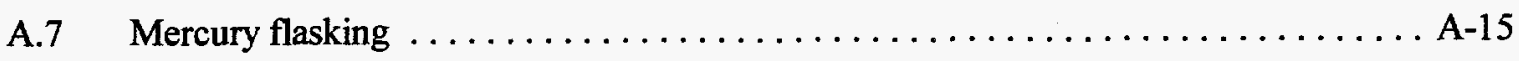

A.8 Steam coil replacement $\ldots \ldots \ldots \ldots \ldots \ldots \ldots \ldots \ldots \ldots \ldots \ldots \ldots \ldots \ldots \ldots \ldots \ldots \ldots \ldots \ldots$

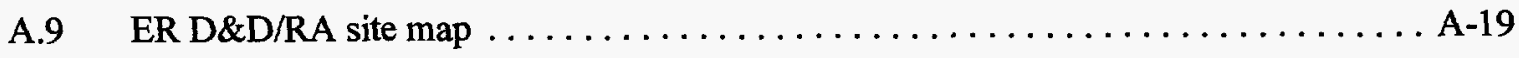

A.10 Aerial overview of the West Borrow Area $\ldots \ldots \ldots \ldots \ldots \ldots \ldots \ldots \ldots \ldots \ldots \ldots \ldots \ldots \ldots$

A.11 Sediment pond before restoration $\ldots \ldots \ldots \ldots \ldots \ldots \ldots \ldots \ldots \ldots \ldots \ldots \ldots \ldots \ldots \ldots$

A.12 Sediment pond during restoration $\ldots \ldots \ldots \ldots \ldots \ldots \ldots \ldots \ldots \ldots \ldots \ldots \ldots \ldots \ldots \ldots \ldots \ldots \ldots$

A.13 Sediment pond after restoration $\ldots \ldots \ldots \ldots \ldots \ldots \ldots \ldots \ldots \ldots \ldots \ldots \ldots \ldots \ldots \ldots \ldots \ldots \ldots \ldots \ldots$

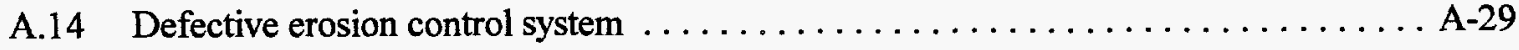

A.15 Restored erosion control system $\ldots \ldots \ldots \ldots \ldots \ldots \ldots \ldots \ldots \ldots \ldots \ldots \ldots \ldots \ldots \ldots \ldots \ldots$ 



\section{ABBREVIATIONS}

\begin{tabular}{ll} 
Alpha-3 & Building 9201-3 \\
Alpha-4 & Building 9201-4 \\
Colex & column exchange \\
CERCLA & Comprehensive Environmental Response, Compensation, and Liability Act of \\
1980 & \\
D\&D & decontamination and decommissioning \\
DOE & Department of Energy \\
DP & Defense Programs \\
EM-40 & Office of Environmental Management \\
ER & Environmental Restoration \\
FFA & Federal Facilities Agreement \\
FMO & Facilities Maintenance Organization \\
FOS & Facility Oversight and Surveillance \\
HAZWOPER & Hazardous Waste Operations \\
HSWA & Hazardous and Solid Waste Amendment \\
LiOH & Lithium Hydroxide \\
Energy Systems & Lockheed Martin Energy Systems \\
NPDES & National Pollutant Discharge Elimination System \\
ORNL & Oak Ridge National Laboratory \\
RA & Remedial Action \\
RI/FS & Remedial Investigation/Feasibility Study \\
RCRA & Resource Conservation and Recovery Act \\
ROD & Record of Decision \\
S\&M & Surveillance and Maintenance \\
SAMIS & Surveillance and Maintenance Information System \\
SWMU & Solid Waste Management Unit \\
TDEC & Tennessee Department of Environment and Conservation \\
TSCA & Toxic Substances Control Act of 1976 \\
WTSD & Waste Transportation and Storage Disposal \\
Y-12 Plant & Oak Ridge Y-12 Plant \\
\hline
\end{tabular}



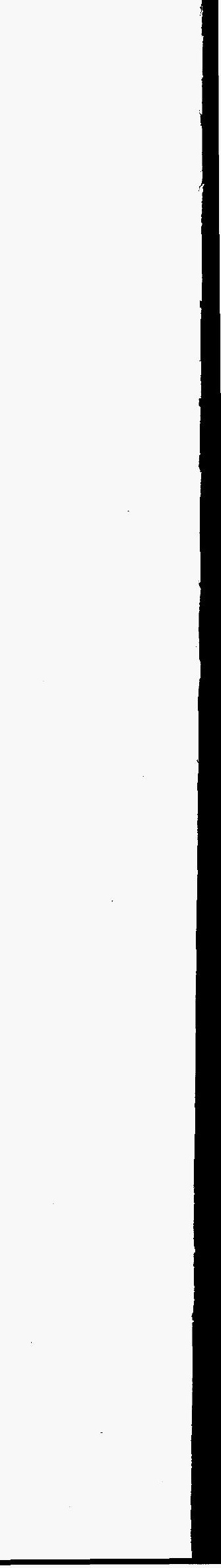


\section{EXECUTIVE SUMMARY}

The mission of the Y-12 Environmental Restoration (ER) surveillance and maintenance (S\&M) operation is to manage in a safe, cost-effective, and efficient manner the S\&M activities for the ER facilities at the Y-12 Plant. S\&M operations are applied to ER support facilities, remedial action (RA) sites, and decontamination and decommissioning (D\&D) activities as the first step to arrest contaminant migration, protect the safety and health of site workers and the public, safeguard the environment from releases from contaminated sites and facilities, and assure support facilities remain available to perform their intended use when required.

This operation provides surveillance and maintenance activities for the U.S. Department of Energy (DOE) Y-12 Plant Environmental Restoration organization, Decontamination and Decommissioning (D\&D) Program facilities, and Remedial Action sites. The primary objective of S\&M operations is to implement actions, primarily routine tasks, that ensure ER D\&D facilities and RA sites remain in compliance with established criteria that protect human health, the environment, and related DOE assets.

Major operations that were accomplished as a result of these objectives are as follows:

- Clean up of two absorber rooms was completed significantly reducing the mercury vapor levels in the building. Over one thousand pounds of clean elemental mercury were collected during clean up operations while producing less than two hundred pounds of non-recyclable waste. Additionally, large quantities of nickel, copper, and aluminum were identified for recycle.

- Approximately 250,000 square feet of floors, walls, and associated equipment were characterized as RAD contaminated, cleaned, painted (as needed), and declared RAD free. This completed enriched uranium operations work in conjunction with the facility stabilization of Alpha-4.

- A process was implemented to remove the mercury from 26,000 gallons of lithium hydroxide (LiOH) solution stored at Alpha-4. Approximately 10,000 gallons have been processed and the remainder will be completed in the first half of FY 1997. The majority of the byproduct (lithium chloride) will be used in the Y-12 Plant cooling systems. Less than one hundred gallons (two 55-gallon drums) of non-recyclable waste will be generated by the entire program.

- Two-hundred-twenty-seven drums were transferred from the 9201-4 permitted Resource Conservation and Recovery Act of 1976 (RCRA) storage area to long-term storage locations at the K-25 Site; 227 drums and five B-25 boxes remain in the storage area at Alpha-4.

- Recovery of mercury from equipment, pipes, and tanks in Alpha-4 resulted in the collection of approximately 9,000 pounds of clean elemental mercury and an additional 1,000 pounds was collected during clean up of two absorber rooms. The mercury was sampled, analyzed, flasked, and prepared for transfer to the Y-12 Plant warehouse.

- Upgrades to the building emergency light and exit sign systems were completed. Additionally, a number of upgrades to electrical systems and isolation of control centers were completed.

- All RA scheduled and required inspections were performed on time.

- There were no regulatory deficiencies or findings during inspections or audits of RA sites. 
- A site maintenance documentation and tracking system for RA facilities was developed and implemented.

- Personnel negotiated and received the last three of seven RCRA post-closure permits and completed semiannual groundwater monitoring required by RCRA permits or Comprehensive Environmental Response, Compensation, and Liability Act of 1980 (CERCLA) Records of Decision (RODs). A groundwater plume delineation well was installed as required by state permit, and all groundwater monitoring reports required by RCRA post-closure permits were completed.

- Personnel developed a training manual for RA facility site inspections and implemented a formal training program for site inspectors as required by RCRA post-closure permits. 


\section{INTRODUCTION}

The Oak Ridge Y-12 Plant Decontamination and Decommissioning (D\&D) and Remedial Action (RA) programs are part of the Environmental Restoration (ER) Division and are funded by the Office of Environmental Management (EM-40). Building 9201-4 (known as Alpha-4), three sites located within Building 9201-3 (the Oil Storage Tank, the Molten Salt Reactor Experiment Fuel Handling Facility, and the Coolant Salt Technology Facility), and Building 9419-1 (the Decontamination Facility) are currently the facilities at the Y-12 Plant included in the D\&D program. The RA program provides surveillance and maintenance (S\&M) and program management of ER sites at the Y-12 Plant, including selected sites listed in Appendix $\mathrm{C}$ of the Federal Facilities Agreement (FFA), sites listed in the Hazardous and Solid Waste Amendment (HSWA) permit Solid Waste Management Unit (SWMU) list, and sites currently closed or undergoing post-closure activities under the Resource Conservation and Recovery Act of 1976 (RCRA) or the Comprehensive Environmental Response, Compensation, and Liability Act of 1980 (CERCLA).

This report communicates the status of the program plans and specific S\&M activities for the D\&D and RA programs.

\subsection{BACKGROUND}

\subsubsection{D\&D}

Alpha-4 began operating in 1945 as a uranium enrichment facility using the electromagnetic separation process for uranium separation and enrichment. However, by 1947 the Oak Ridge Gaseous Diffusion Plant had demonstrated a superior ability to produce enriched uranium in sufficient quantities, and the electromagnetic process was abandoned. The building was not used again until 1953 when the installation of the column exchange (Colex) process began. Facility retrofits were completed in 1955, the year the process began operation. The Colex operation involved an electrochemical and solvent extraction process that required substantial quantities of mercury as a solvent to separate lithium- 6 from lithium-7 in the form of lithium hydroxide. The Colex process was discontinued in 1962, and the equipment was drained of the majority of processing materials including mercury. However, all system components were not cleaned, and residual trace amounts of mercury and lithium hydroxide remain in the process equipment and lines. EM-40 assumed full ownership of the facility in 1993 and provided S\&M through the Y-12 Plant D\&D program.

Alpha-4 is currently in the inactive-shutdown phase and is part of an ongoing S\&M activity which is preparing the building for safe-and-secure shutdown status. The three Alpha-3 sites and the decontamination building, 9419-1, originally under the scope of the ORNL D\&D program, were transferred to the D\&D and are part of that program. S\&M activities are being accomplished through

- risk mitigation,

- hazard abatement, and

- $\quad$ site preparation for subsequent D\&D and/or long-term S\&M for the shutdown of the buildings/sites. 


\subsubsection{Remedial Action}

The Y-12 ER RA S\&M program was established at the start of FY 1993 to manage contaminated inactive sites from the time of the discovery of the contamination until the initiation of RAs and any subsequent monitoring or maintenance. These sites are, or potentially are, typically contaminated with radioactive materials and/or hazardous chemicals. Prior to 1993, these activities were conducted by and under the Y-12 Plant defense programs (DP) scope of responsibility. Because the Y-12 Plant is currently a multi-program site, many of the facilities have undergone, and are still undergoing, numerous changes in "ownership". RA S\&M sites have been selected based on one of more of the following criteria:

- the site is inactive, or actively or primarily supporting ER programs/projects;

- the site is formally and programmatically under ER jurisdiction; and

- characteristics of the site are such that the integrity of the site and risk reduction/avoidance will benefit from the activities within the scope of the S\&M program.

\subsection{OBJECTIVES OF THE Y-12 PLANT ER DECONTAMINATION AND DECOMMISSIONING/REMEDIAL ACTION PROGRAMS}

The strategic goals of the Y-12 Plant ER D\&D/RA programs are to protect human health and the environment plus reduce the number of hazardous-material-contaminated facilities by properly managing and disposing of the facilities when they are no longer required to fulfill a site mission. The D\&D objectives are as follows: (1) to provide S\&M activities and facility stabilization in support of facilities that are on standby and are awaiting D\&D; (2) to develop specific methods, schedules, and funding for the D\&D of shutdown facilities; and (3) to implement plans to provide for facility disposition in a safe, compliant, and cost-effective manner. The RA objectives are as follows: (1) to assess the baseline and manage, in a safe, cost-effective, and efficient manner the S\&M activities for the ER sites at the Y-12 Plant; (2) to support facilities and RA sites as a first step to arrest contaminant migration; (3) to protect the safety and health of site workers and the public; (4) to safeguard the environment from releases from contaminated sites and facilities; (5) to assure support facilities perform their function as intended; and (6) to provide monitoring and maintenance of closed facilities as required by post-decision documents (e.g., Records of Decision (RODs) or RCRA post-closure permits).

The primary objective of S\&M operations is to implement actions, primarily routine tasks, that focus on ensuring that ER D\&D facilities and RA sites remain in compliance with established criteria that protect human health, the environment, and related DOE assets.

\subsubsection{Technical Objectives}

- S\&M operations will continue as interim activities at D\&D sites until a facility is actively engaged in a demolition project or until it is decontaminated/refurbished to the extent that it can be released for an alternative use.

- One-time facility stabilization actions are conducted at ER sites/facilities including removing legacy materials/waste from facilities or sites, mitigating facility hazards, limiting access to contaminated sites and facilities, improving safety, and recovering valuable assets from abandoned or surplus equipment. 
- S\&M operations at RA sites include post-closure monitoring and maintenance as required by RCRA post-closure permits or CERCLA RODs.

- ER facilities and sites will be assessed to establish a baseline of health, safety, risk, and environmental compliance.

\subsubsection{Management Objectives}

Management objectives include the following:

- complete scheduled tasks and deliverables on time.

- reduce risk by implementing specific actions.

- identify methods to improve the operations and/or reduce costs.

- define and maintain management controls and performance reporting.

\section{FISCAL YEAR 1996 SURVEILLANCE}

ER facilities and sites were maintained in an environmentally safe condition through an ongoing surveillance program. Each surveillance program was tailored to fit unique aspects of each facility.

\subsection{D\&D}

There were no active production systems in operation at the D\&D facilities. Daily surveillance activities by building personnel monitored overall building and structural integrity, condition of piping/plumbing, condition of stored materials, environmental issues, hazardous materials, mercury vapor levels, and facility cleanup. Water from underground springs which collected in the eight Alpha-4 building sumps was monitored for the presence of mercury and discharge volume records were maintained. Mercury vapor levels were checked twice daily and results were charted and trended. All assigned personnel participated in a monthly urinalysis program designed to provide information on mercury exposure levels. Facility surveillance was conducted by the facility manager, personnel assigned to Alpha-4, other Y-12 Plant personnel, Lockheed Martin Energy Systems (Energy Systems) personnel, and U.S. Department of Energy, state, and federal government officials. Areas of primary interest and concern included the following:

- visual inspection of the facility and equipment for structural deficiencies, material degradation, leaks, unusual odors, or abnormal conditions;

- $\quad$ routine checks of primary and secondary containment systems for the presence of any liquid buildup or level change;

- checks of building ventilation systems;

- observation of sump flow rates, storage and integrity, and dikes around storage tanks;

- verification of facility environmental control systems and utilities; and

- inspection of all emergency exits, stairways, emergency lights and exit signs. 


\subsection{REMEDIAL ACTION SURVEILLANCE AND INSPECTION}

The achievement and maintenance of a level of excellence in environmental compliance are accomplished through the cooperative efforts of Energy Systems, Tennessee State Regulators, and the DOE team. The guiding principles for this team were (1) adhere to a sufficient set of standards that meet the performance expectations and goals for the work while providing adequate protection to the environment, workers, and the public, and (2) invoke only the standards which are necessary for surveillance activities to be sufficient. This was further refined by (1) defining minimum requirements to achieve compliance, (2) evaluating and proposing alternative methods of achieving compliance objectives, and (3) identifying other standards or best management practices in an effort to optimize effectiveness and efficiency. Surveillances and inspections under the RA program include the following actions:

- weekly inspections of 6 RCRA and 2 Toxic Substances Control Act (TSCA) sites/facilities,

- monthly inspections of 13 RCRA post-closure and 4 Non-RCRA post-closure sites/facilities,

- quarterly inspections of 7 RCRA post-closure and 1 CERCLA ROD sites/facilities,

- semiannual inspections of 11 other closed sites or study areas,

- $\quad$ site access control,

- monthly building manager's inspection of two facilities,

- weekly facility managers' facility oversight and surveillance (FOS) of sites and facilities,

- semiannual groundwater and surface water monitoring as required by RCRA/CERCLA decision documents; and

- inspection/maintenance of groundwater monitoring wells.

\section{SAFETY AND SECURITY/PROTECTION SYSTEMS}

\subsection{ACCESS CONTROL}

\subsubsection{D\&D}

Alpha- 4 is located on the west end of the Y-12 Plant within the exclusion area. This affords a higher level of control and protection of the area by plant security personnel. Access to Alpha- 4 is through a single entry point on the second floor of the building which contains the administrative and office area and entry point for the remainder of the building which is a hazardous waste operations (HAZWOPER) site. Access is controlled via a roto-gate and can be activated only by those employees who are current in all requirements for access to a HAZWOPER site and have a specific need/reason to be in the building. Requirements include (1) current 24h or 40h HAZWOPER training and an annual $8 \mathrm{~h}$ refresher thereafter, site/building briefing, medical evaluation, three day on-the-job training, and a specific reason for access. Persons not meeting these requirements or not maintaining currency are denied unescorted access. The three facilities located in Alpha-3 and Building 9419-1 are located in the east end of the plant and access is controlled by securing all entry points (locked), posting signs specifying entry requirements, and using a contact point for entry. 


\subsubsection{Remedial Action}

Due to the reservation-wide locations of the RA sites, access control and security of each area are governed by the location of the site and the level of control required for each. Sites within the security areas of the Y-12 Plant have a level of control required for access to the particular secure area. Additional measures, such as physical barriers (fences, barricades, or flagging) and posted warnings are used to augment the controls which are in place to control day-to-day plant access. Remotely located sites outside the confinement of the immediate plant boundaries are controlled by (1) fences which delineates the boundaries of the site, and (2) gates which restrict vehicular and pedestrian traffic. Administrative controls such as signs and hazard warnings are also posted at each site if appropriate.

\subsection{SAFETY AWARENESS}

\subsubsection{D\&D}

On February 9, 1994, a Daily Safety Meeting program was begun in Alpha-4 to bring greater emphasis on safety to the forefront of each operation, task, and job being performed in the facility. During this time period two major decontamination projects were completed, three absorber rooms cleaned, numerous electrical upgrade projects were completed, and the facility was prepared for a "safe-and-secure shutdown." This equates to more than 123,000 employee hours worked without a lost workday incident or restricted workday case. Concurrently, during this time other personnel not assigned to Alpha-4 were working in the facility temporarily which accounts for an additional 10,000 hours.

\subsubsection{REMEDIAL ACTION}

The preponderance of activities conducted as part of RA S\&M activities involves analytical lab personnel, well monitoring/sampling personnel, well maintenance subcontractors, maintenance organizations, and other support groups. During FY 1996, 10,000 employee hours were utilized inspecting sites, evaluating results, and providing facility maintenance. All activities were accomplished without an injury or safety incident. Due to the diversity of work required, acreage maintained, remote location, and difficulty of access, working injury free for FY 1996 was a major safety accomplishment.

\section{ACCOMPLISHMENTS}

Fiscal year 1996 was a hallmark year for D\&D and RA activities at the Y-12 Plant. Major activities were completed to place Alpha-4 in a "safe-and-secure shutdown" status, four facilities were added to the D\&D program, and RA requirements for inspections were formalized in the Y-12 Plant Surveillance and Maintenance Program Facility Inspections and Training Requirements Manual. The following description presents an overview and detailed compilation of the activities and accomplishments of the D\&D and RA programs for FY 1996: 


\subsection{D\&D}

- Efforts to reduce mercury vapor levels within Alpha-4 continued during FY 1995. Work begun in the absorber rooms proceeded through the end of FY 1996. Significant reductions in mercury vapor levels were recorded in all areas as noted in Fig. A.1 and Fig. A.2. Additionally, more than 1000 pounds of clean elemental mercury was collected, analyzed for purity, flasked, and placed in storage. Substantial quantities of steel and copper were removed and large amounts of nickel and aluminum were identified, checked, and found to be clean for recycling. This was accomplished safely, efficiently, and cost-effectively in conjunction with the mercury vapor mitigation program. Less than 150 pounds of waste products requiring special handling was produced during the accomplishment of this project. The overall reduction of mercury vapor levels is a key factor in maintaining a high level of confidence in placing the building in a safe-and-secure shutdown status.

- A second key element of preparation for safe-and-secure shutdown was the elimination of radiological contamination areas. During FY 1996 more than 246,172 square feet of floors, walls, and assorted pieces of equipment were decontaminated, cleaned, or coated which protective covering to remove/reduce any radiological hazards (Fig. A.3). Decontamination personnel utilized a broad variety of equipment ranging from a bead blaster, pneumatic chisels, and vacuum cleaners to hand scrapers, cleaning rags and ordinary detergents to clean the areas. All work performed by the decontamination crew was directed toward the clean up of both fixed and transferable radiological contamination.

- A third key element was the isolation of electrical control centers throughout the building. Completion of this vital phase of work assured that there were no unidentified or abandoned circuits which could accidentally be reenergized. Concurrently, upgrades to the emergency lights and installation of new exit signs were completed (Fig. A.4). These two safety code projects were essential to successfully meet the criteria for safe-and-secure shutdown.

- The evaluation of the building ventilation system was completed. The importance of building ventilation as one of the major controlling factors in maintaining/managing mercury vapor levels for the facility cannot be over stressed and was critical in the overall plan. Fan upgrades were completed giving building operations personnel a $100 \%$ increase in flexibility of choice in rates of air flow and areas to ventilate and the ability to manage the building's atmospheric environment.

- Two-hundred-thirty-seven of the drums stored in the permitted RCRA area were shipped to a storage site at the K-25 facility or transferred to other storage sites at the Y-12 Plant. This completed two years of effort by ER, Waste Transportation and Storage Disposal (WTSD), and Waste Management to review, evaluate, sample, overpack, prepare, and ship $95 \%$ of RCRA material stored in Alpha-4 (Fig. A.5).

- Treatment of 10,000 gallons of lithium hydroxide ( $\mathrm{LiOH})$ was completed. Approximately 16,000 gallons remain which will be treated by the end of December 1996. The initiation of the process was the culmination of four years of work to develop an efficient and cost-effective process for removing any traces of mercury from the $\mathrm{LiOH}$ solution. A process was developed using equipment and process applications which were already available (Fig. A.6). This accomplishment reduced the original cost estimates from the Y-12 Plant Development Organization for completing the project by $25 \%$. The output from the process was water which was released through a National Pollutant Discharge Elimination System (NPDES) permitted outflow and lithium chloride (cathene) which will be reused in the plant cooling systems. The only non-usable products from the process are small amounts of silicate material, filters, and some sludge. 
- An engineering evaluation/cost analysis was completed for the removal of a hydrogen line and a mercury feed line which were part of the original process system for Alpha-4. These lines are outside and have the highest probability/potential for an uncontrolled mercury release to the environment. Plans include the removal of both lines during FY 1997.

- More than 10,000 pounds of elemental mercury (1,000 pounds from the absorber rooms, 9,000 pounds from the remainder of the building) were recovered during clean up operations in Alpha-4 (Fig. A.7). This further reduced the vapor levels within the facility and was another key element in preparing for a safe-and-secure shutdown status.

- Efforts to reduce utility costs (steam, electrical, and water) continued in FY 1996. Building utility systems were checked and any leaks or problem areas repaired. The building steam heat system was enhanced with the replacement of four defective steam coils (Fig. A.8).

\subsection{REMEDIAL ACTION}

- All scheduled and required inspections were performed on time.

- Personnel developed and implemented a site maintenance documentation and tracking system for RA facilities (Fig. A.9). This provided a management tool for establishing maintenance priorities and a means to ensure that required maintenance was performed in a timely manner.

- There were no regulatory deficiencies or findings observed during inspections or audits.

- The RA program took control of the East and West Borrow areas. Workers implemented a program to regulate access to the areas and began erosion abatement and reseeding programs. A number of the sediment control basins were cleaned of sediment to reestablish their effectiveness and erosion control systems were revitalized. These actions were instrumental to a silt-free discharge at the NPDES outfall, and improved overall site stability (Figs. A.10 through A. 15).

- Personnel negotiated and received the last three of seven remaining RCRA post-closure permits. Implementation of terms and conditions of all seven permits is ongoing.

- Personnel completed semiannual groundwater monitoring as required by RCRA permits or CERCLA RODs.

- The Y-12 Surveillance and Maintenance Program Facility Inspection Training Manual (Y/ER/MS-1) was developed. Site Inspectors received annual training as required by RCRA post-closure permits.

- Workers installed, completed, and sampled a groundwater plume delineation well as required by RCRA post-closure permit.

- All groundwater monitoring reports required by RCRA post-closure permits were completed and transmitted to Tennessee Department of Environment and Conservation (TDEC)-DSWM prior to required deadlines.

- All required annual well inspections and maintenance activities were completed.

- The RCRA groundwater detection monitoring requirements at New Hope Pond were eliminated through negotiations of terms and conditions of the RCRA permit. Monitoring is deferred to the CERCLA RI/FS process. 


\section{GOALS FOR FISCAL YEAR 1997}

The accomplishments of FY 1996 established the foundation for a strong program in both D\&D and RA activities for FY 1997. A number of planning sessions have taken place and short, intermediate, and long range program objectives were established. The following tasks will be the primary focus of the D\&D and RA program for FY 1997.

\subsection{D\&D}

- Complete the treatment of the $\mathrm{LiOH}$ solution and clean any sludge/residue from the storage tank

- Maintain the level of control and inspection of the Building 9201-3 sites and Building 9419-1 to ensure that all remain within the required regulatory compliance guidelines.

- Complete absorber room clean up to further reduce mercury vapor levels within the facility.

- Place Building 9201-4 in safe-and-secure shutdown condition to minimize the S\&M of the building.

- Remove the external piping associated with the Colex process materials which poses the greatest risk for an uncontrolled release of mercury to the environment.

\subsection{REMEDIAL ACTION}

- Expand the Facility Inspection Training Manual to include additional RA facilities.

- Comply with all permit and regulatory requirements.

- Implement cost-savings measures identified during FY 1996 in the groundwater monitoring program, such as elimination of redundancies in monitoring among the various programs at the Y-12 Plant.

- Incorporate system improvements and update site and facility information using the Surveillance and Maintenance Information System (SAMIS) as an S\&M management tool to better manage facility and site information.

- Improve management and control of the East and West Borrow Areas through their inclusion in the RA S\&M program.

- Assess various FFA Appendix C sites at the Y-12 Plant for which internal ownership and control of the sites is in question. The sites will be assessed to determine their current regulatory status and their health and safety compliance. The objective of this goal is to determine appropriate site controls and responsibilities. 
Appendix

REPRESENTATIVE FIGURES AND SITE MAP 



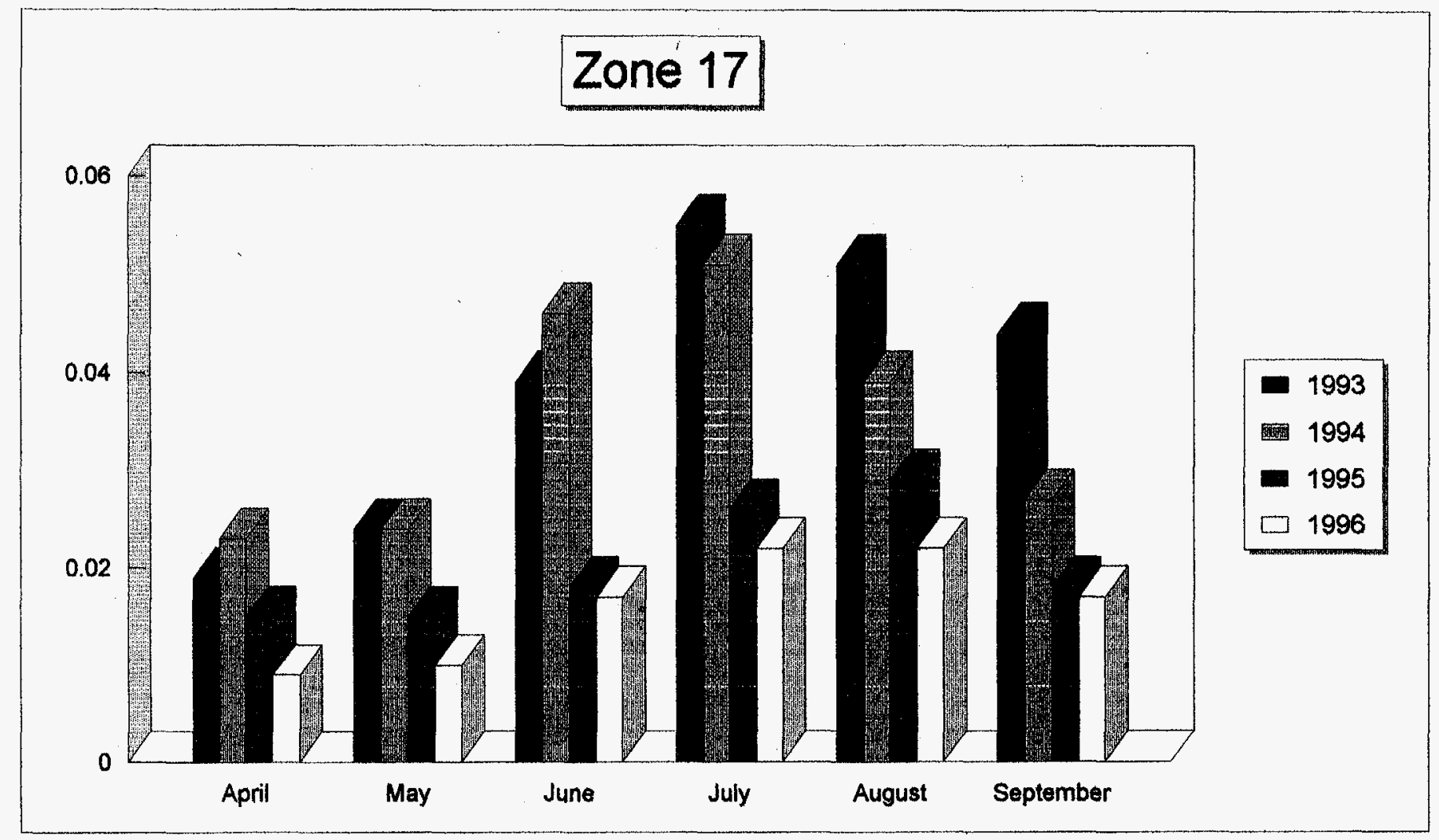

Fig. A.1. Zone 17 mercury vapor levels for six-month period, 1993-1996. Mercury vapor level readings are taken in each area (zone) twice daily. The threshold limit value (TLV) is 0.025 milligram of mercury per cubic meter of air, and any area above that reading requires respiratory protection for work in that area. One main effort has been to reduce mercury vapor levels in Alpha-4. This chart compares mercury vapor level reductions from 1993 to 1996 in zones which contained large quantities of mercury and contributed to the overall mercury vapor levels for the building. During FY 1996, even with clean up work in progress, mercury vapor level averages were consistently below TLV. This significantly reduced personal protective equipment requirements, job difficulty, and time spent to complete jobs. 



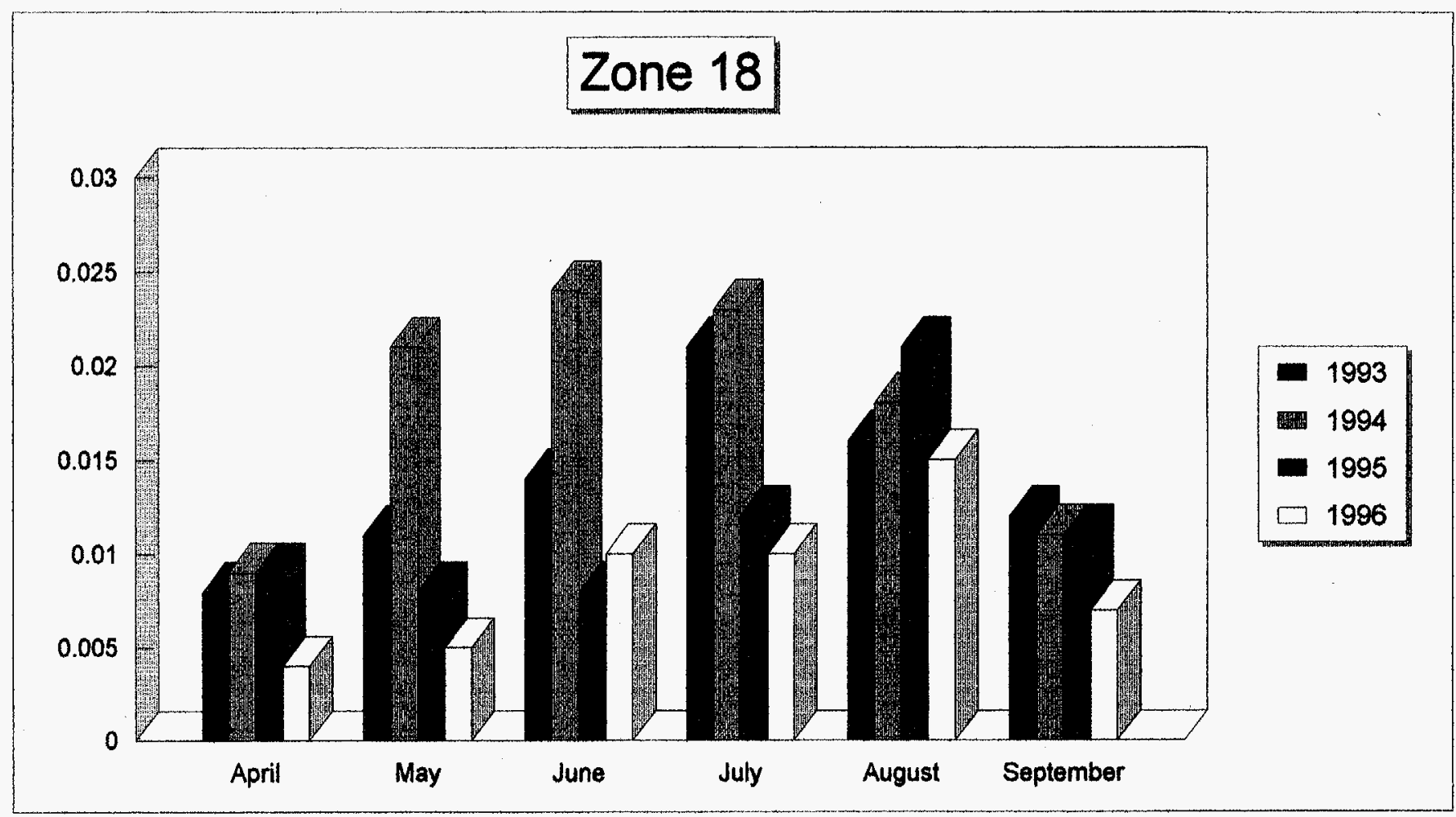

Fig. A.2. Zone 18 mercury vapor levels for six-month period, 1993-1996. Mercury vapor level readings are taken in each area (zone) twice daily. The threshold limit value (TLV) is $\mathbf{0 . 0 2 5}$ milligram of mercury per cubic meter of air, and any area above that reading requires respiratory protection for work in that area. One main effort has been to reduce mercury vapor levels in Alpha-4. This chart compares mercury vapor level reductions from 1993 to 1996 in zones which contained large quantities of mercury and contributed to the overall mercury vapor levels for the building. During FY 1996, even with clean up work in progress, mercury vapor level averages were consistently below TLV. This significantly reduced personal protective equipment requirements, job difficulty, and time spent to complete jobs. 



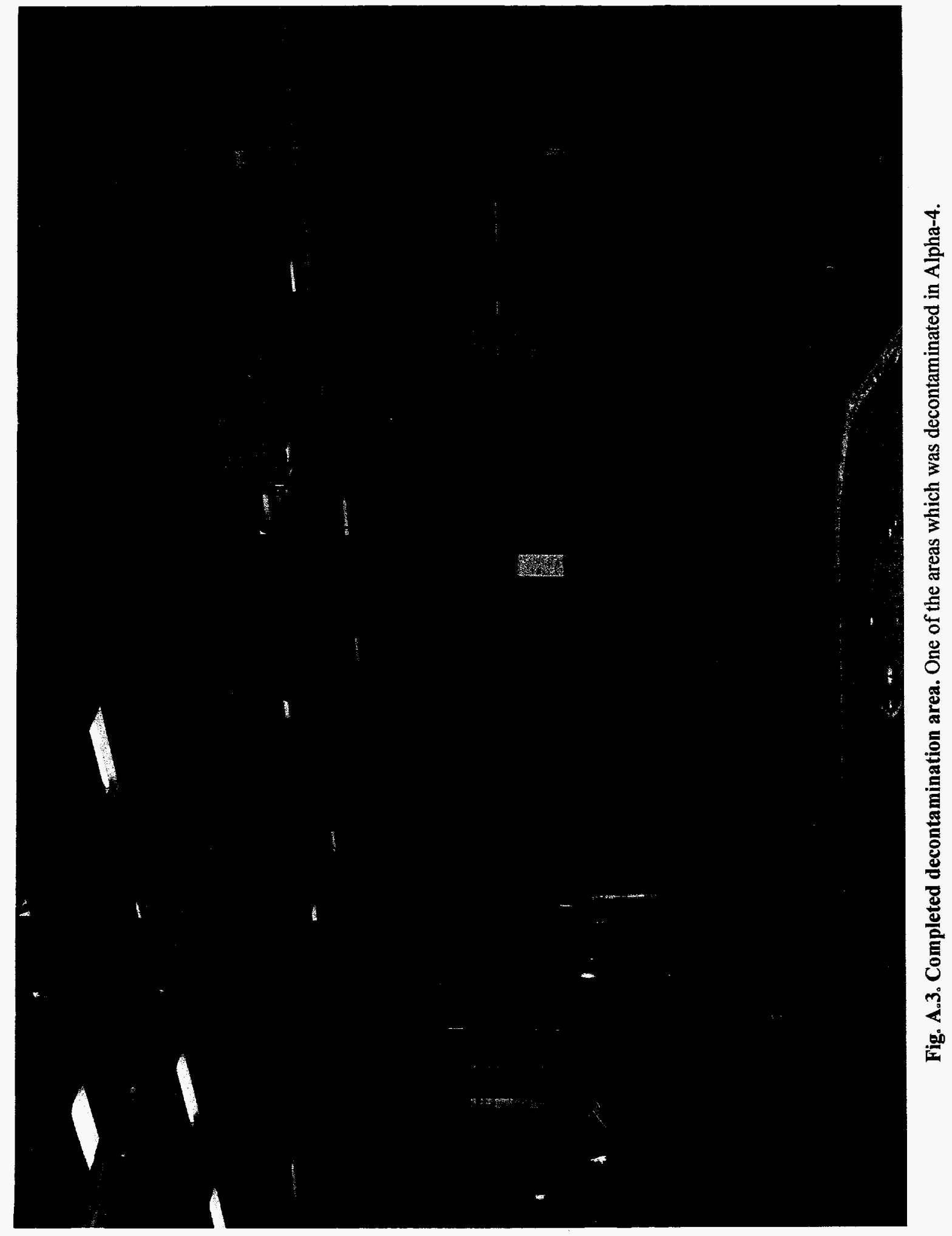




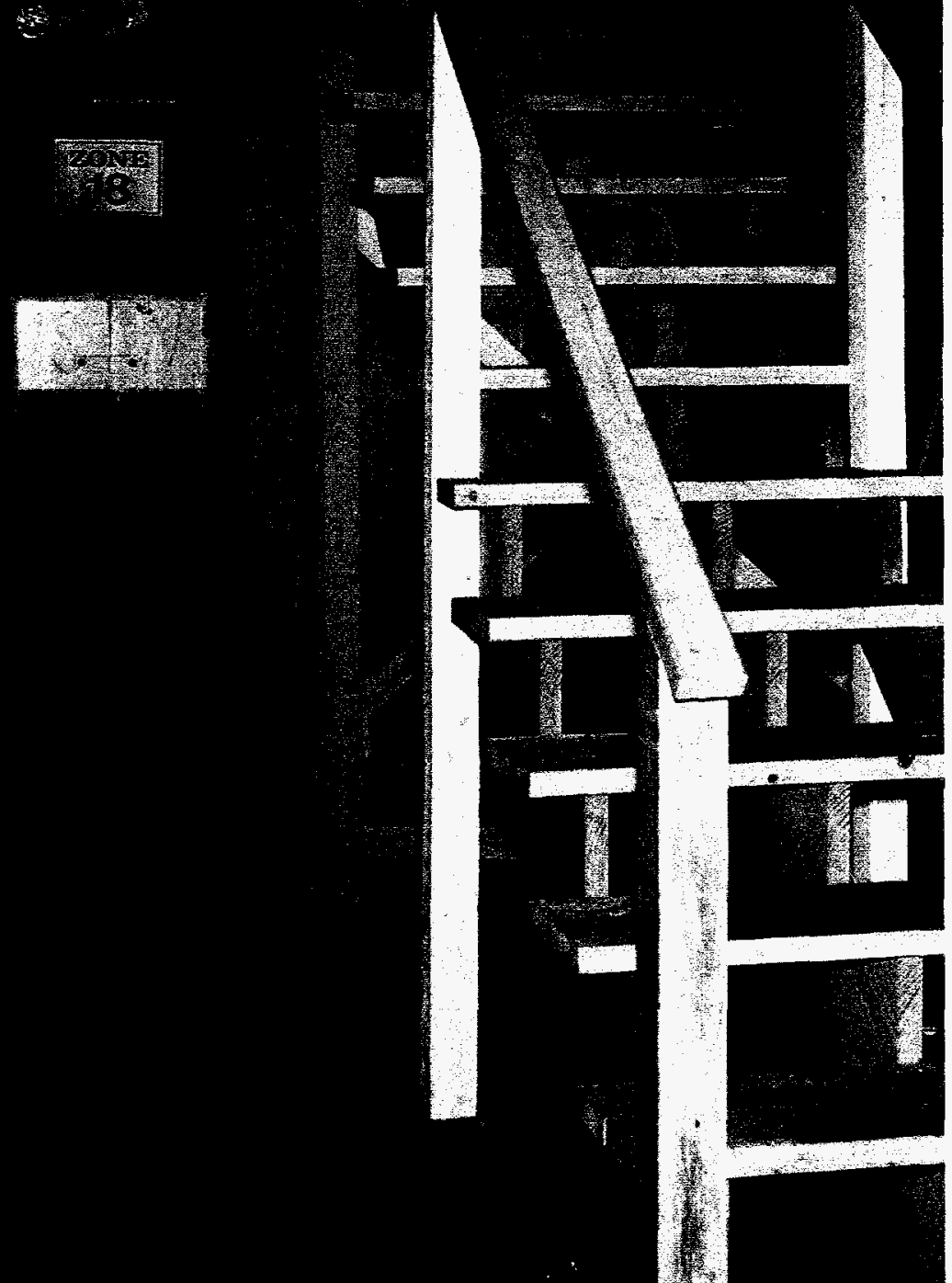

Fig. A.4. Safety upgrades. Safety upgrades for the exit and emergency lights were completed. Stairways were added at the end of elevated work stations to reduce the traveling distance to emergency exits. 

11

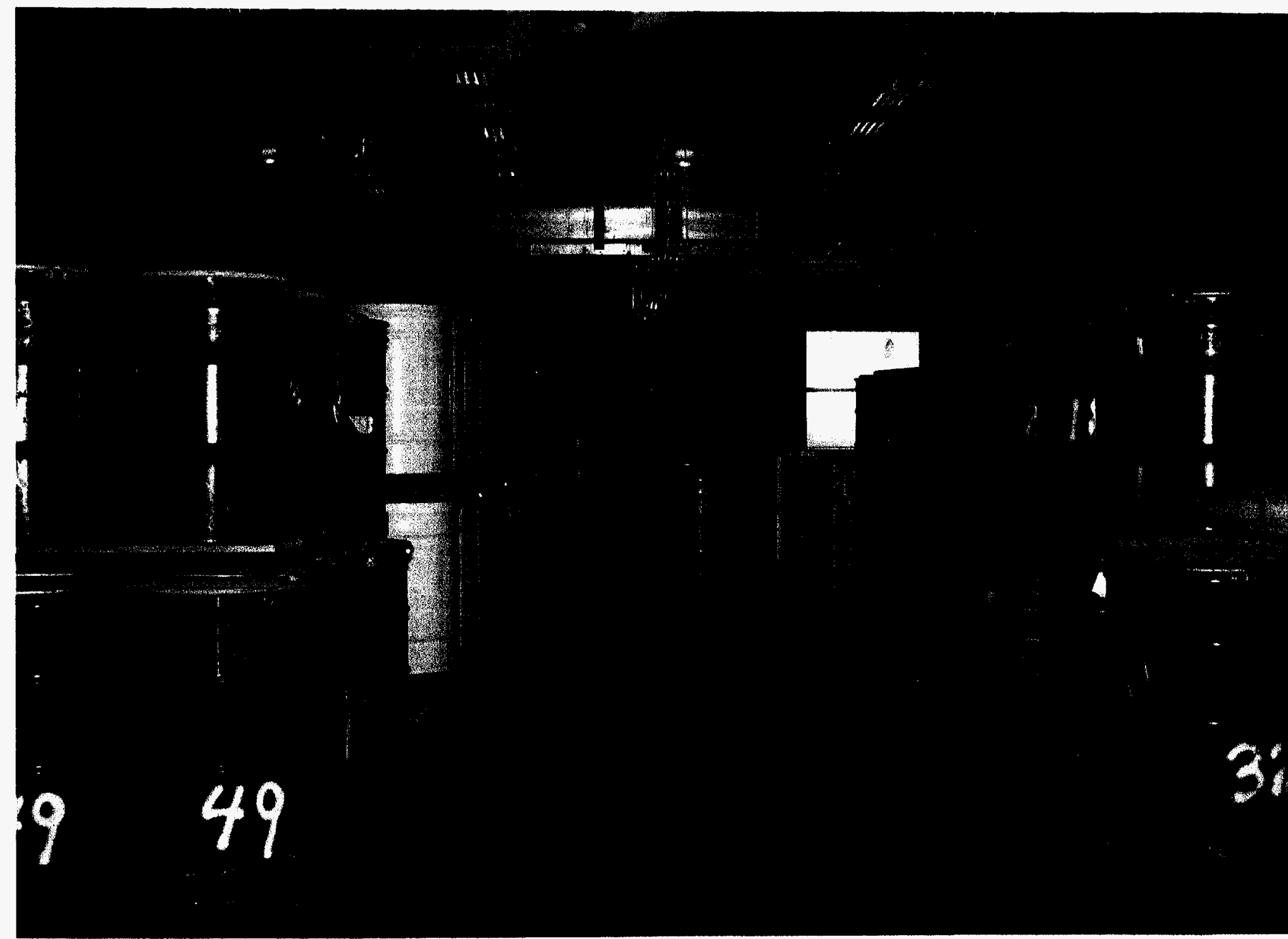

Fig. A.5. Permitted RCRA storage area. Drums stored in the RCRA permitted area were processed, placed in 85 gallon overpacks (large white drums), and labeled; 227 drums were shipped to a long-term storage facility. 



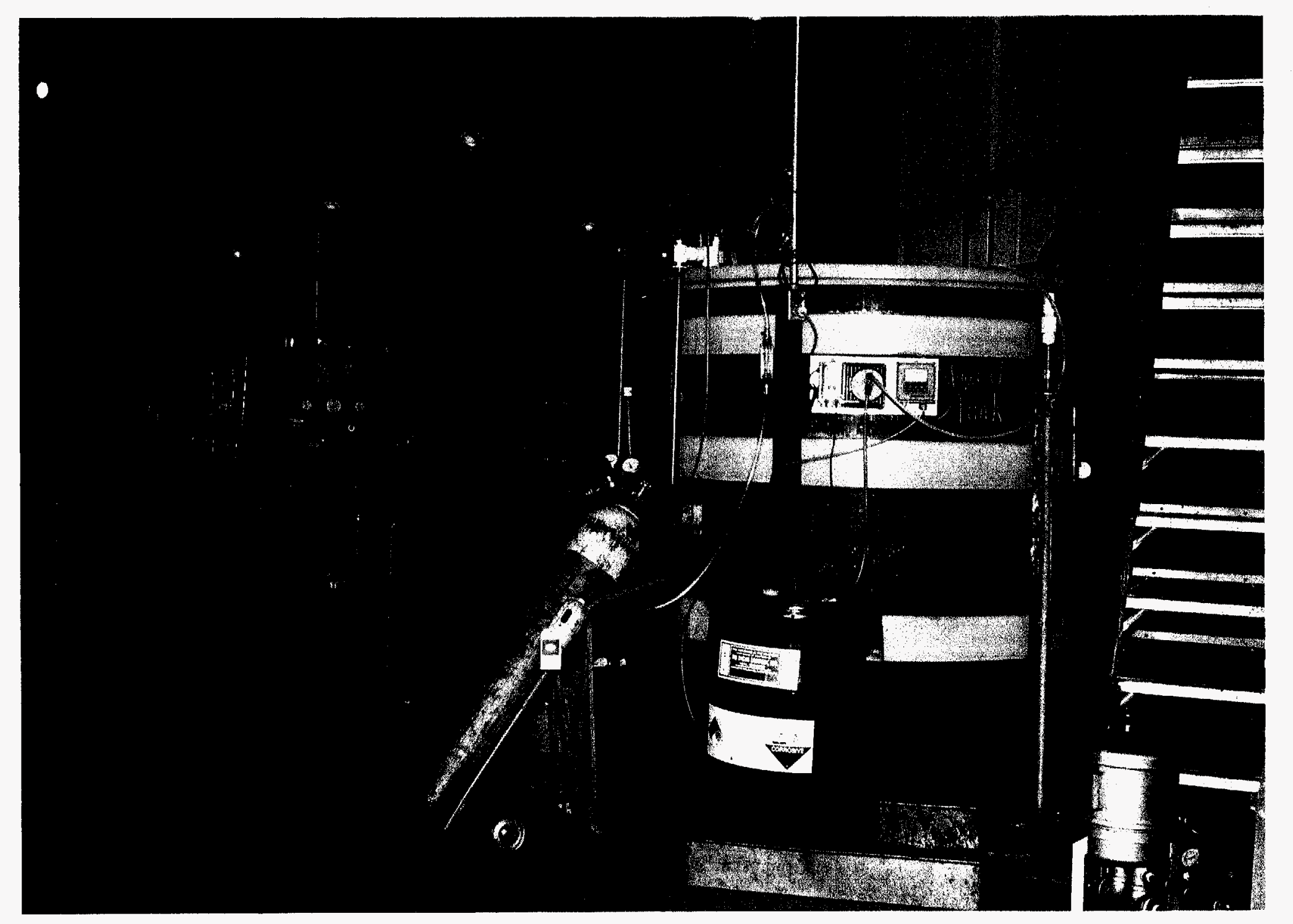

Fig. A.6. Mercury and lithium hydroxide treatment area. A process to remove the mercury and lithium hydroxide was developed in collaboration with ORNL and Y-12 personnel. Eighty percent of the final design incorporated available equipment and proven chemical processing techniques. 



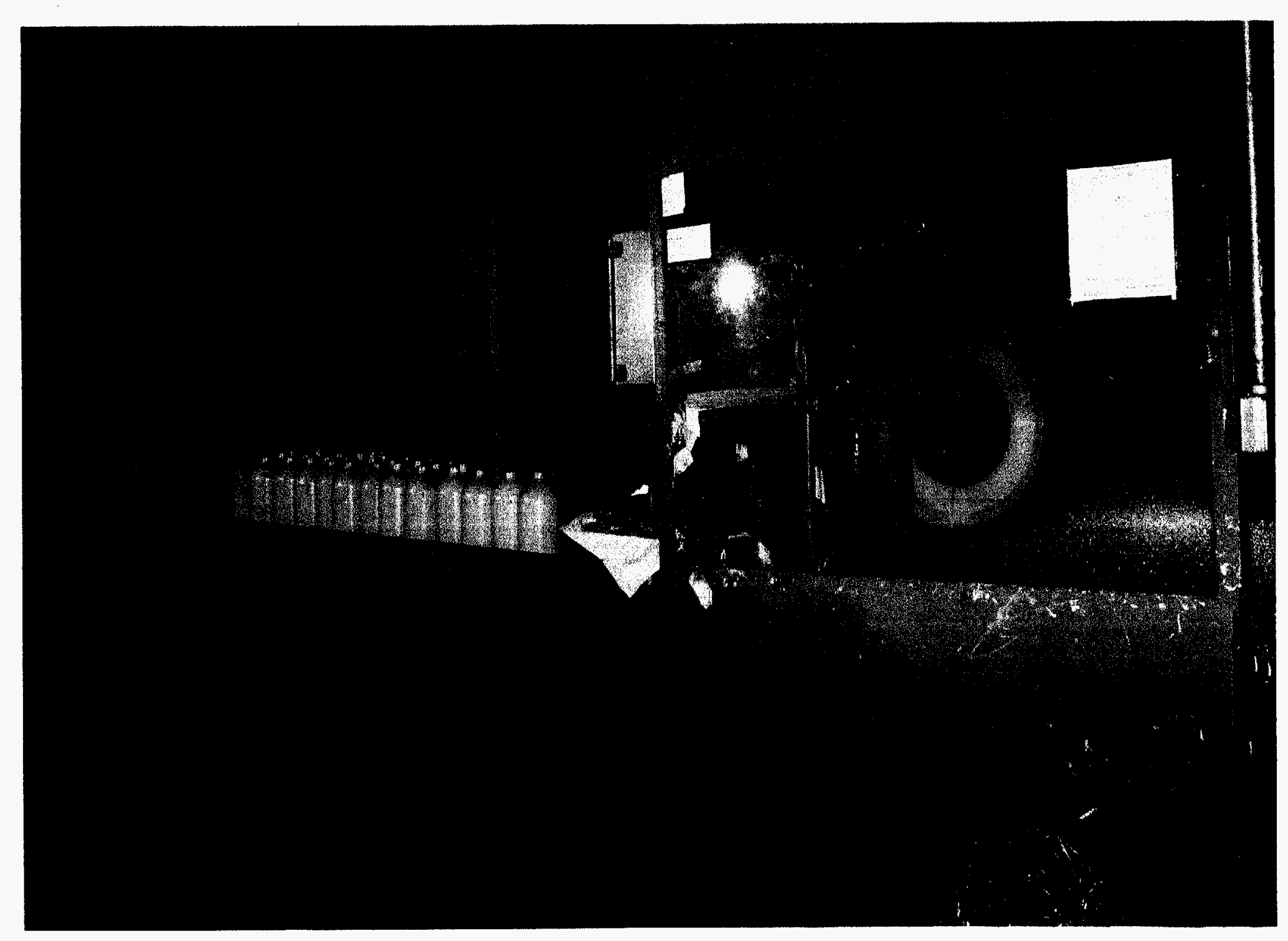

Fig. A.7. Mercury flasking. Routine maintenance and day-to-day operations yielded several thousand pounds of clean elemental mercury. Additionally, pipes and equipment were cleaned netting in excess of 10,000 pounds of mercury. Shown is the flasking station where 76 pounds of mercury was put in each flask. 



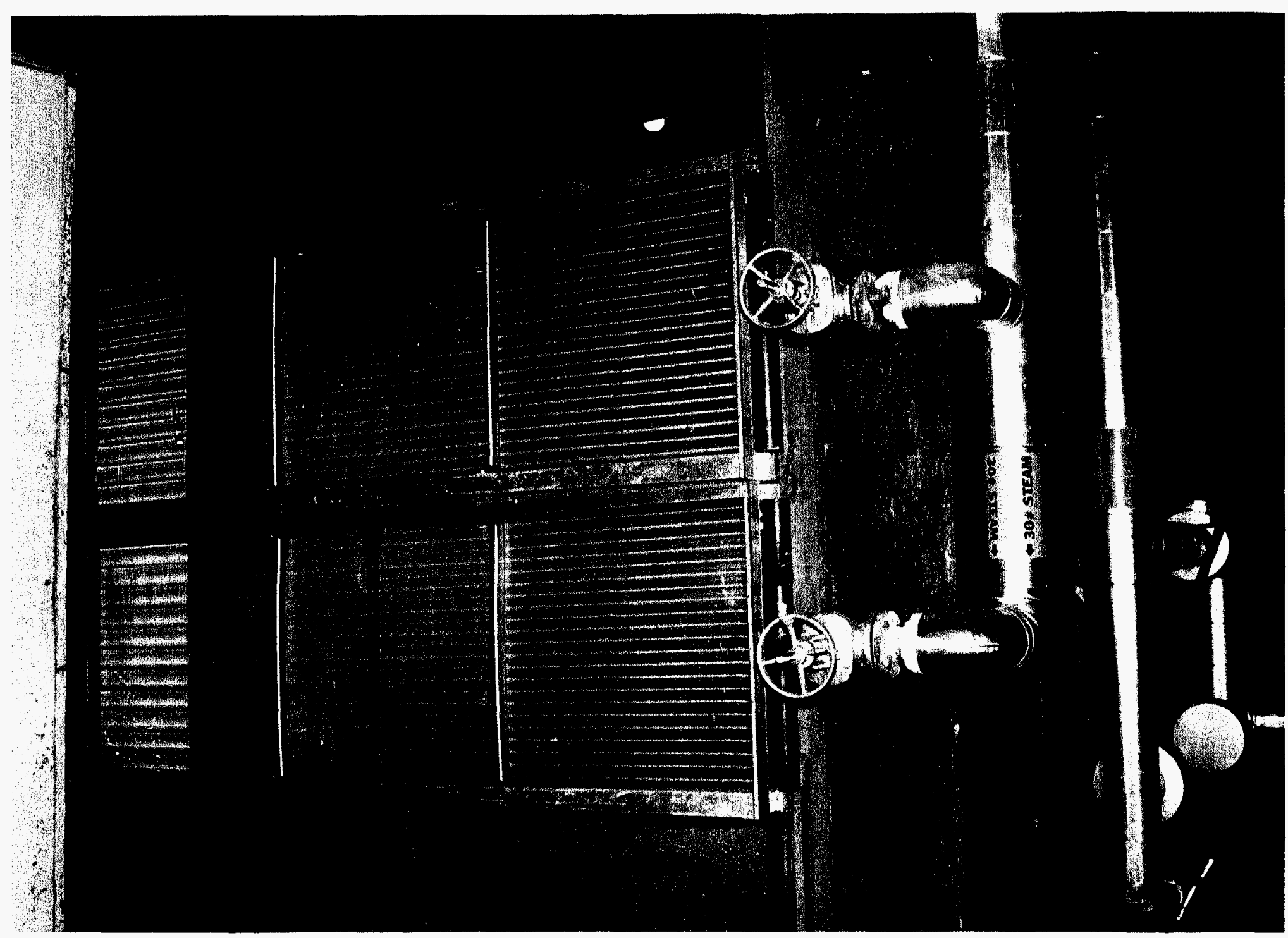

Fig. A.8. Steam coil replacement. Four defective steam coils were replaced in conjunction with upgrades to electrical, steam, ventilation, and associated building systems. These upgrades were critical in preparing for safe-and-secure shutdown. 



\section{NOTICE}

Page(s) size did not permit electronic reproduction. Information may be purchased by the general public from the National Technical Information Service, U.S. Department of Commerce, Springfield, VA 22161 (Area Code 703-487-4650). DOE and DOE contractors may purchase information by contacting DOE's Office of Scientific and Technical Information, P.O. Box 62, Oak Ridge, TN 37831, Attn: Information Services (Area Code 423-576-8401). 



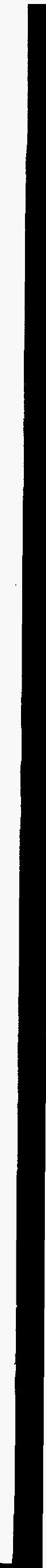




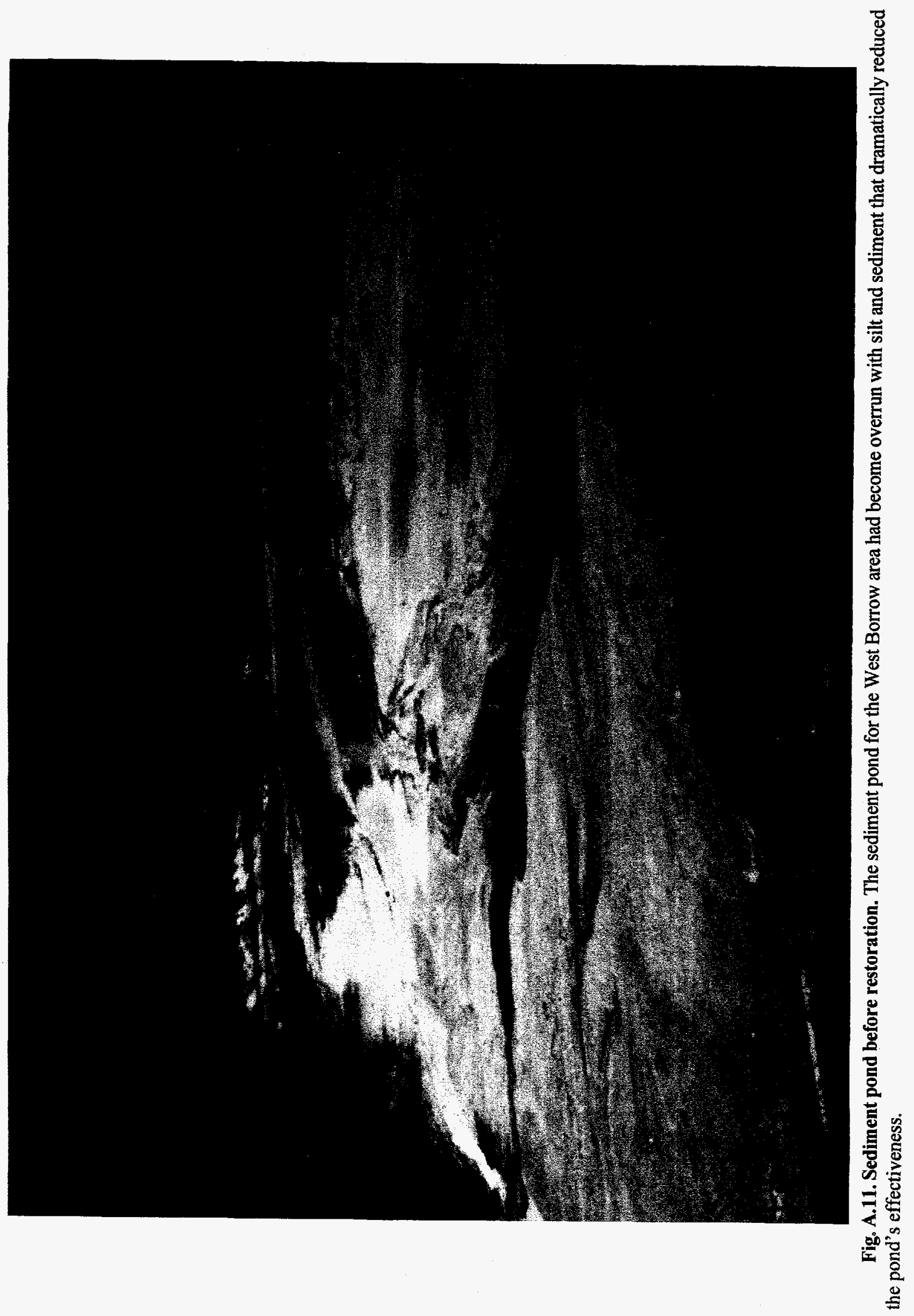





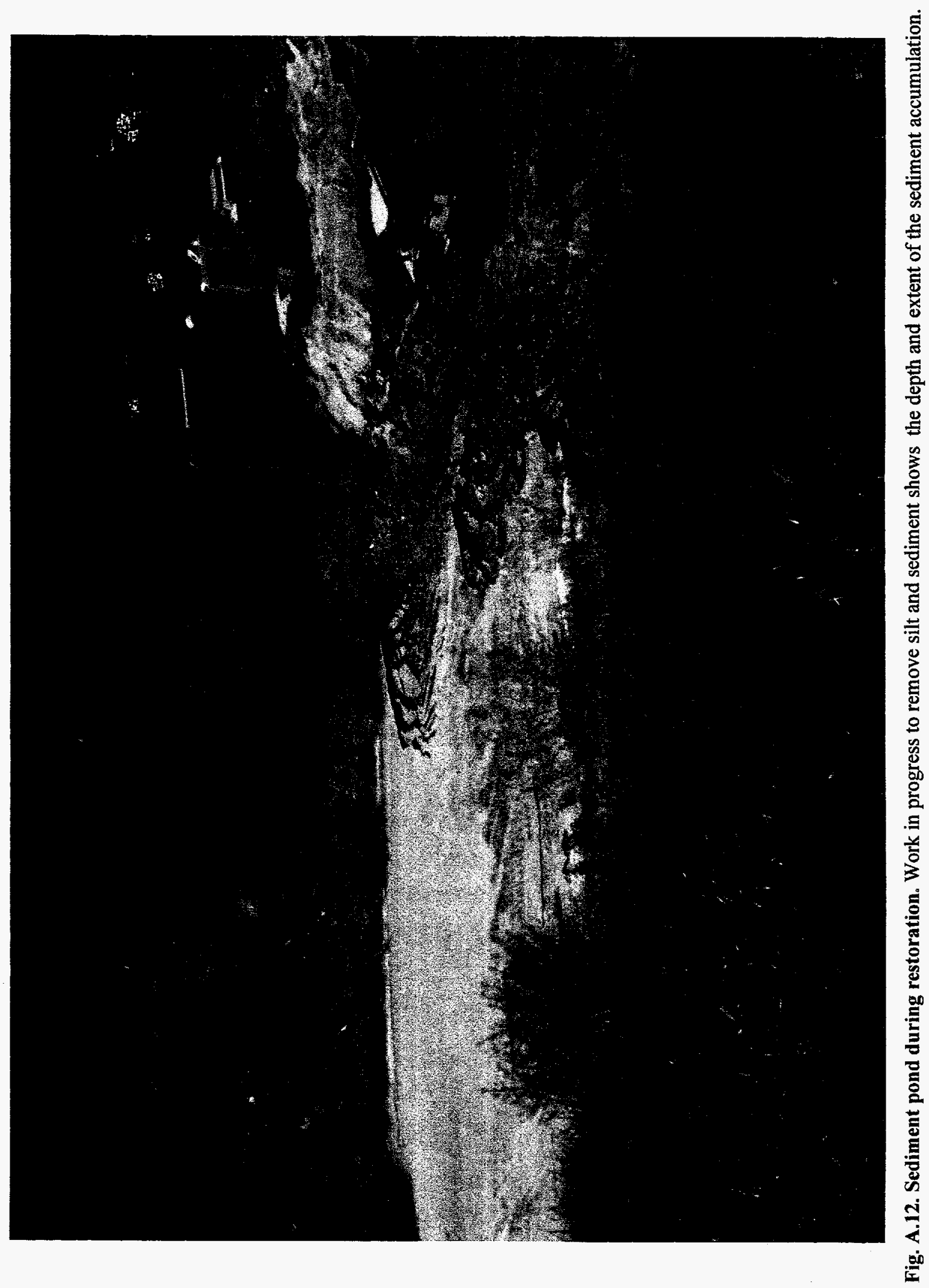





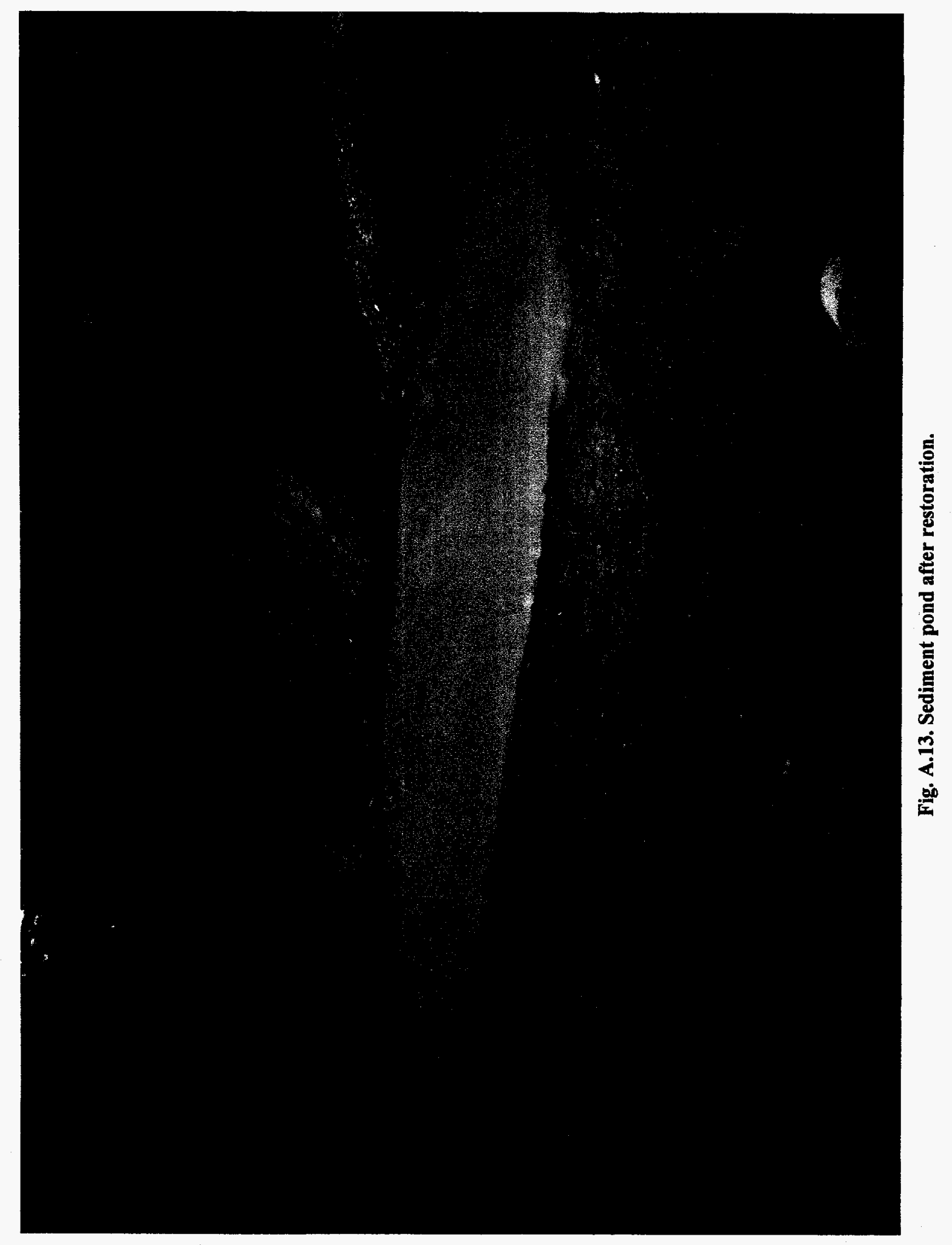





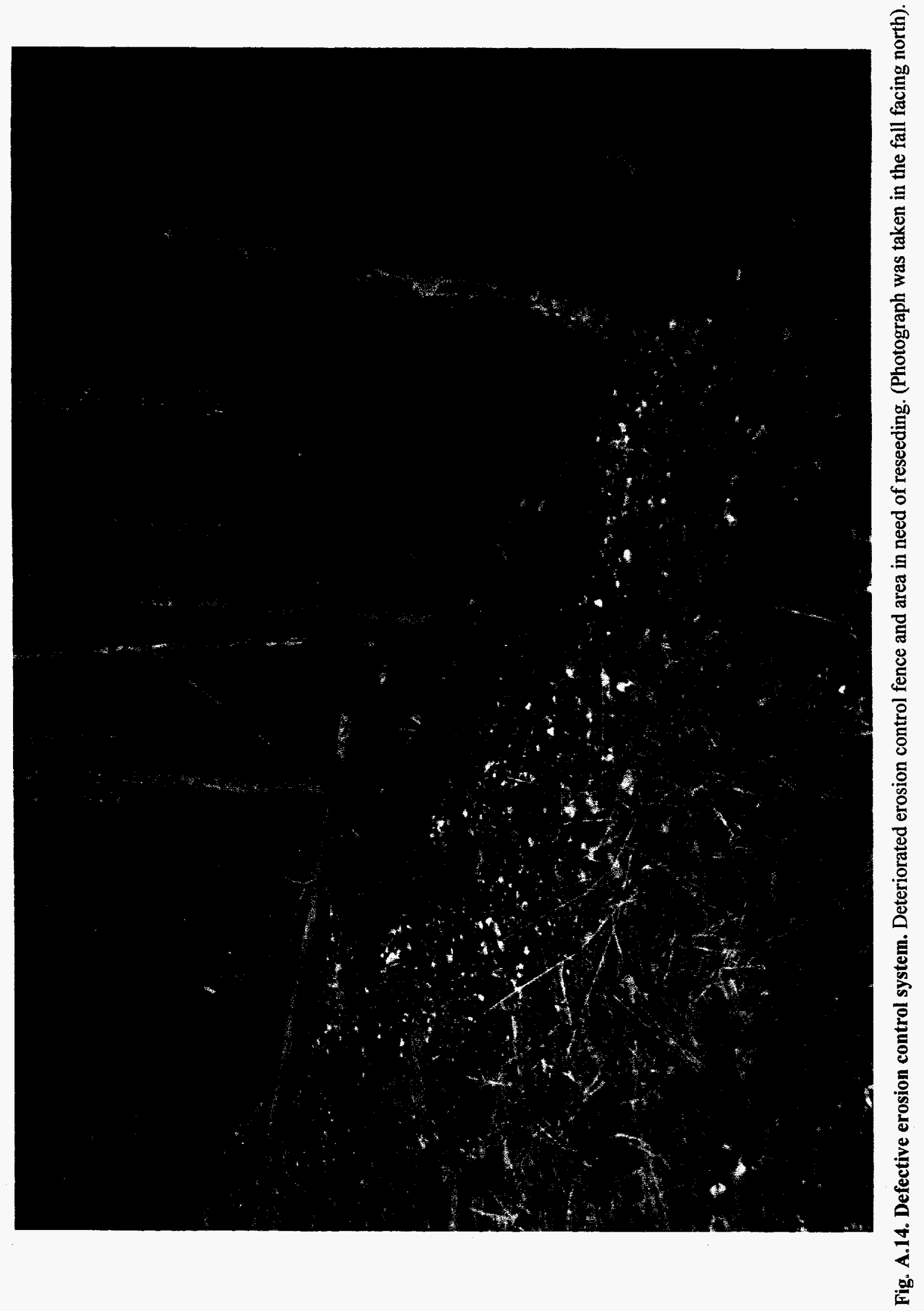



A-31

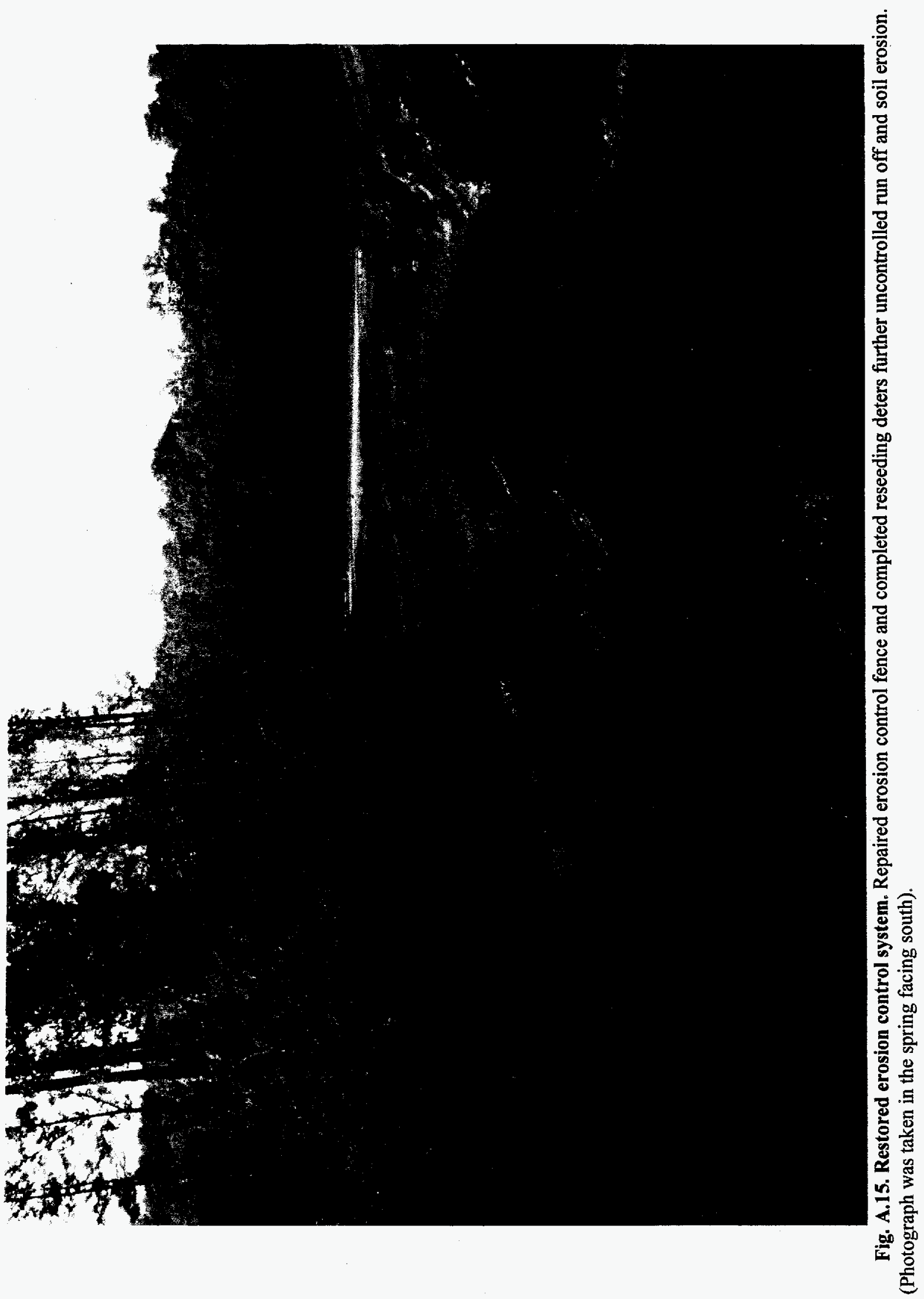




\section{DISTRIBUTION}

1. L. V. Asplund

2. K. A. Bradley

3. T. W. Burwinkle

4. T. R. Butz

5. D. G. Cope

6. W. S. Gibson

7. F. P. Gustavson

8. C. P. Hall

9. R. E. Hawthorne/P. W. Standifer

10. J. E. Heiskell/J. E. Stone

11. S. A. Herron

12. S. H. Howell

13. B. H. Kimmel

14. J. R. Lyons, II

15. D. M. Matteo

16. T. A. Morris

17. H. C. Newsom

18. P. T. Owen

19. M. L. Sollenberger

20-24. D. E. Sparkman. Jr.

25. Y-12 Central Files

26. ER Document Management Center-RC

27. R. C. Sleeman, Director, Environmental Restoration Division, DOE Oak Ridge Operations Office, P.O. Box 2001, Oak Ridge, TN 37831-8541 